\title{
IMPACT OF A TEST METHOD ON THE UNDRAINED SHEAR STRENGTH OF A CHOSEN FLY ASH
}

\author{
Andrzej Gruchot ${ }^{1}$, Tymoteusz Zydroń ${ }^{1}$
}

1 Department of Hydraulic Engineering and Geotechnics, Faculty of Environmental Engineering and Geodesy, University of Agriculture in Kraków, Adama Mickiewicza 24/28, 30-059 Kraków, Poland, e-mail: rmgrucho@ cyf-kr.edu.pl, t.zydron@ur.krakow.pl

Received: 2016.06.11

Accepted: 2016.08.10

Published: 2016.09.20

\begin{abstract}
The paper presents an assessment of the suitability of a laboratory vane apparatus, a cone penetrometer as well as a shear vane tester and a pocket penetrometer for determination of the parameters of the undrained shear strength of fly ash from the Power Plant "Skawina". The suitability of the cone penetrometer and the laboratory vane apparatus for the determination of the undrained shear strength of the fly ash has been shown. On the bases of the obtained test results, , drained and undrained shear strengths of the subsoil made of the fly ash under the square pad foundation were calculated according to Eurocode 7. The calculations of the ultimate resistance of the drained subsoil showed that it was several times bigger than its value in undrained conditions. This confirms the need for the proper determination of the angle of internal friction and cohesion as well as the undrained shear strength of fly ashes.
\end{abstract}

Keywords: fly ash, shear strength, ultimate resistance of the subsoil

\section{INTRODUCTION}

In Poland, production of the electric and thermal energy is based mainly on burning hard or brown coal, which generates significant amounts of minestone wastes, and in particular fly ashes and ash-slag mixtures. Depending on the quality and calorific value of the coal and its ash content for every kilowatt-hour of the produced electricity and heat, from 35 to $220 \mathrm{~g}$ of wastes are produced [Zabielska-Adamska 2006, Pisarczyk 2009].

Geotechnical properties of fly ashes vary in a wide range depending on the type, origin and degree of fragmentation of the used coal, the technology and temperature of combustion and the manner of storage. That is why it is important to recognize correctly their properties, in particular shear strength parameters, thereby enhancing the applicability of these wastes in earth structures [Baran et al. 2013, Gruchot et al. 2015].

In engineering practice, according to the Eurocode 7 , ultimate resistance of a subsoil, which depends on its structure and the considered state of stress, should be determined at undrained or drained conditions. At the drained conditions, it is required to determine the angle of internal friction and cohesion, which is performed in the direct shear apparatus or triaxial compression apparatus. However, undrained shear strength required in the calculations of the ultimate resistance at the undrained conditions can be determined by both field and laboratory tests. At the laboratory tests, triaxial compression or cylindrical torsion apparatuses are the most commonly used, but also a cone penetrometer and a laboratory vane apparatus.

\section{PURPOSE AND SCOPE OF WORK}

The paper aimed at an assessment of the suitability of the laboratory vane apparatus, the cone penetrometer as well as so called handheld instruments (shear vane tester, pocket penetrometer) for determination of shear strength parameters of fly ash collected from the chute of electrostatic precipitators at the Power Plant "Skawina". Supplementary to the strength characteristics of the 
fly ash, the tests of the angle of internal friction and cohesion were carried out in the direct shear apparatus.

The basic physical properties of the fly ash were determined using standard methods. The granulometric composition was determined by the areometric method, and the density of solid particles by a volumetric flask method in distilled water. The optimum moisture content and the maximum bulk density of solid particles were determined in the Proctor's apparatus in the cylinder of the volume of $1.0 \mathrm{dm}^{3}$, at the compaction energy $0.59 \mathrm{~J} \cdot \mathrm{cm}^{-3}$.

Determination of the undrained shear strength was performed on samples moulded at the moisture content close to as well as $5 \%$ less and greater than the optimum one, until the compaction was corresponding to the degree of compaction $\mathrm{I}_{\mathrm{S}}=$ 0.90 and 1.00 .

The laboratory vane apparatus (Figure 1) makes it possible to determine torque when rotating its tip driven into the soil (Figure 1c). The undrained shear strength $\left(c_{u}\right)$ is calculated assuming a shear surface of a shape of the cylinder, which is determined by the dimensions of the cross-tip of the apparatus, using the formula:

$$
c_{u}=\frac{M}{\pi \cdot D^{2} \cdot\left(\frac{H}{2}+\frac{D}{6}\right)}[k P a]
$$

where: $M-$ maximum torque $[\mathrm{kN} \cdot \mathrm{m}]$, $H, D-$ height and diameter of the vane $[\mathrm{m}]$.
In the presented tests, the used vane had dimensions:

$$
H=D=12.7 \mathrm{~mm} \text {. }
$$

The cone penetrometer enables determination of the depth of penetration of its tip from the sample surface into the soil (Figure 2). The undrained shear strength $c_{u}$ is calculated using the formula [PKN-CEN ISO/TS 17892-6:2009]:

$$
c_{u}=c \cdot g \cdot \frac{m}{i^{2}}[k P a]
$$

where: $c$ - constant depending on the vertical angle of the cone $b$,

$g-$ acceleration of gravity $\left[\mathrm{m} \cdot \mathrm{s}^{-2}\right]$,

$m$ - cone mass [g],

$i$ - depth of the cone penetration [mm].

A cone tip of a mass of $400 \mathrm{~g}$, vertical angle $b=30^{\circ}$ and $\mathrm{c}=0.8$ was used in the carried out tests. Reliable depths of the cone penetration were assumed from the range from 4 to $18 \mathrm{~mm}$ [PN-B-04481:1988]. 3 to 5 measurements were performed on the same soil sample.

Determination of the shear strength using the shear vane tester (Figure 3) consist in the measurement of the torque $\left(M_{f}\right)$ while shearing the soil, which runs on the side and front surfaces of the cylinder specified with dimensions of the vane tip (Table 1). The type of the tip is selected depending on the soil consistency [Myślińska 2006], and a shear strength $\tau_{\max }$ is determined from the formula:
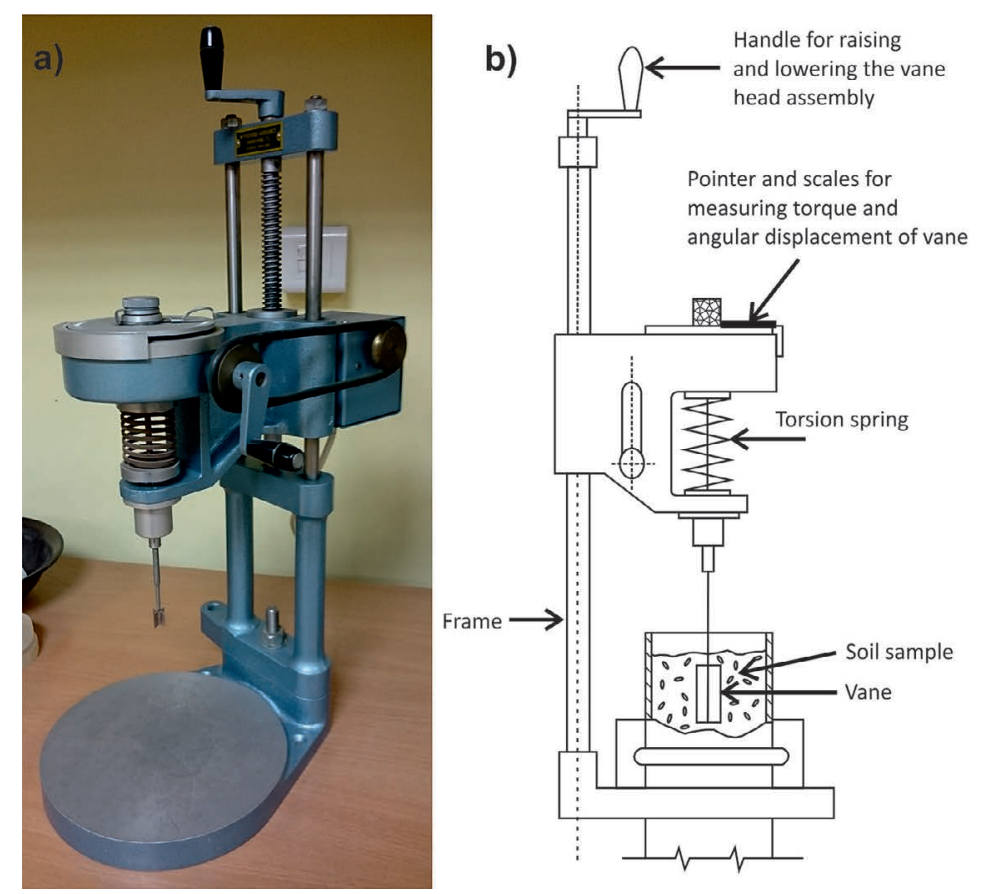

c)

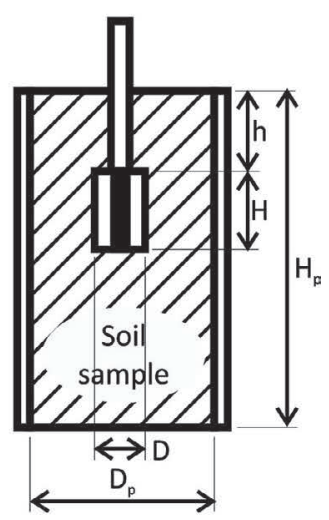

Figure 1. Laboratory vane apparatus: a) general view (photo by A. Gruchot), b) apparatus scheme, c) dimensional requirements of the sample $\left(\frac{D_{p}}{D}>3,5, \frac{H_{p}}{H}>3, h \geq H\right)$ 

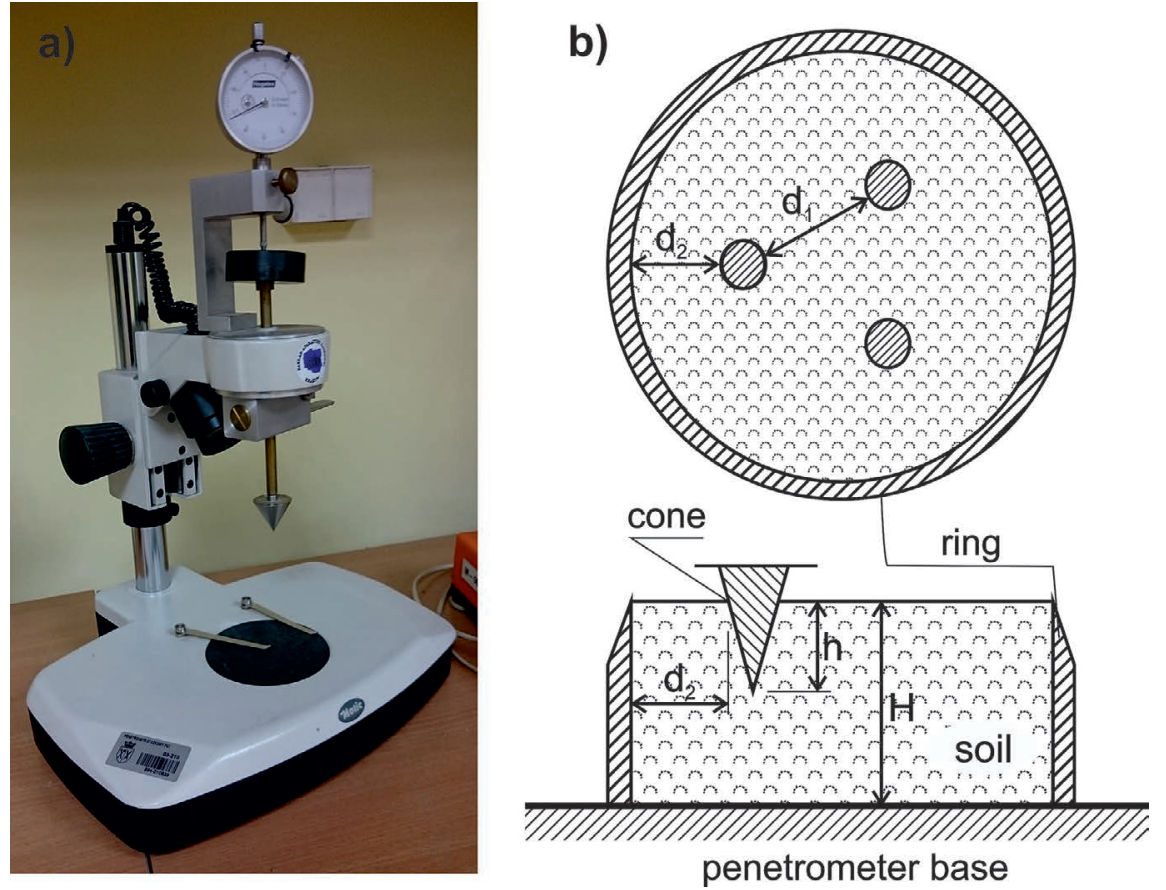

Figure 2. Cone penetrometer: a) general view (photo by A. Gruchot), b) distribution of measuring points $\left(d_{1}, d_{2}\right) \geq 1,5 \cdot h, 2 \cdot h \leq H$ [Glinicki 1995]

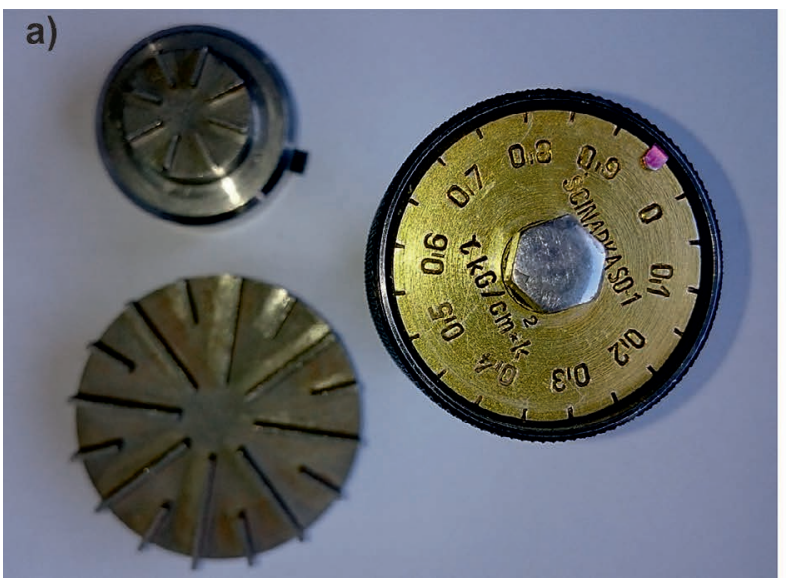

b)
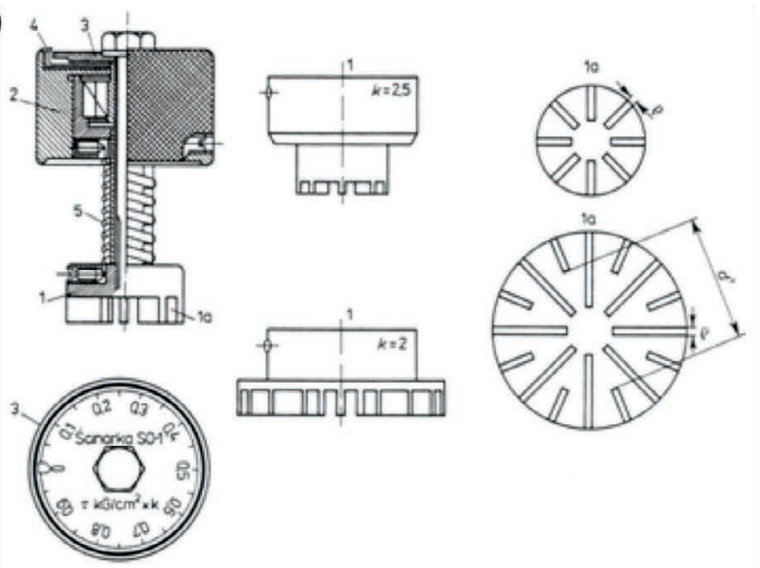

Figure 3. Handheld shear vane tester SO-1: a) general view (photo by A. Gruchot), b) scheme [Myślińska 2006]: $1,1 \mathrm{a}$ - vane tips, 2 - knob, 3 - dial and measurement pointer (4), 5 - spring

$$
\tau_{\max }=M_{f} \cdot K_{T V}[k P a]
$$

where: $M_{f}$ - maximum torque $[\mathrm{kN} \cdot \mathrm{cm}]$,

$K_{T V}-$ coefficient characteristic for a given tip (Table 1).

In these tests, normal tip was used with $K_{T V}$ $=1.0$. A cone penetrometer (Figure 4) makes it possible to determine soil cohesion, assuming $f=0$ and that it corresponds to the ultimate pressing force $Q_{f}$

Determination of the angle of internal friction and cohesion was performed in the direct shear apparatus in a box of dimensions of $8 \times 8 \mathrm{~cm}$ and a height of the sample $4.7 \mathrm{~cm}$ [PKN-CEN ISO/TS

Table 1. Tips dimensions and the values of the coefficient KTV for the shear vane tester [Myślińska 2006]

\begin{tabular}{|c|c|c|c|c|}
\hline Type of the tip & Soil consistency & Tip diameter D [mm] & Vane height $\mathrm{H}[\mathrm{mm}]$ & Coefficient $K_{T V}\left[\mathrm{~cm}^{-3}\right]$ \\
\hline Small & half compact, hard plastic & 20 & 3 & 2.5 \\
\hline Normal & hard plastic, plastic & 26 & 5 & 1.0 \\
\hline Big & softly plastic, smooth & 48 & 6 & 0.2 \\
\hline
\end{tabular}




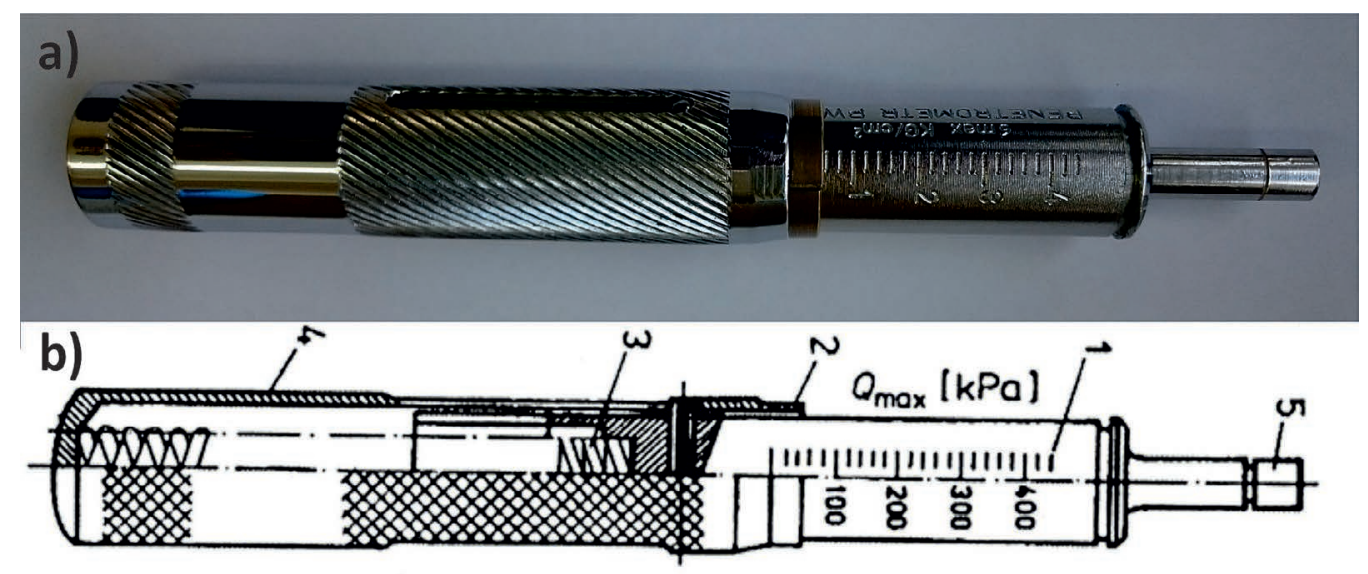

Figure 4. Pocket penetrometer: a) general view (photo by A. Gruchot), b) scheme [Myślińska 2006]: 1 - measurement scale, 2 - indicator ring, 3 - spring, 4 - handle, 5 - cylindrical tip of a diameter of $6.4 \mathrm{~mm}$

17892-10]. The samples were compacted in the apparatus box, at the moisture content close to the optimum one, to obtain a density corresponding to the degree of compaction $\mathrm{I}_{\mathrm{S}}=0.90,0.95$ and 1.00. Consolidation and shearing of the samples were carried out immediately after the compaction, at normal stresses of 100, 200 and $300 \mathrm{kPa}$. The speed of the shearing was $0.1 \mathrm{~mm} \cdot \mathrm{min}^{-1}$. The maximum shear stress value in the range of up to $10 \%$ of horizontal deformations was assumed as a shearing criterion.

On the basis of the results of shear strength obtained from the laboratory vane apparatus and the cone penetrometer tests as well as basing on the values of the angle of internal friction and cohesion, the ultimate resistance of the subsoil made of the fly ash of the compaction corresponding to the degree of compaction $\mathrm{I}_{\mathrm{S}}=0.90$ and 1.00 was analyzed. The calculations were carried out in accordance with the Eurocode 7 [PN-EN 19971:2008] in drained and undrained conditions under a square pad foundation of dimensions $B=L$ $=1.0 \mathrm{~m}$ loaded axially. Then, reducing the resistance of cohesion, attempt was made to find such its value, at which the values of the ultimate resistance in drained and undrained conditions were equal. The ultimate resistance of the subsoil made of fly ash in drained conditions was calculated from the equation [PN-EN 1997-1:2008]:

$R_{d}=\frac{R_{k}}{\gamma_{R}}=\left[\frac{A^{\prime} \cdot\left(\mathrm{c}_{k}^{\prime} \cdot N_{c} \cdot s_{c}+q^{\prime} \cdot N_{q} \cdot s_{q}+0,5 \cdot \gamma^{\prime} \cdot B^{\prime} \cdot N_{\gamma} \cdot s_{\gamma}\right)}{\gamma_{R}}\right]$

whereas this resistance in undrained conditions was calculated from the equation:

$$
R_{d}=\frac{R_{k}}{\gamma_{R}}=\left[\frac{A^{\prime} \cdot\left((\pi+2) \cdot c_{u, k} \cdot S_{c}+q^{\prime}\right)}{\gamma_{R}}\right]
$$

where: $R_{d}-$ design value of the ultimate resistance of the subsoil [kN],

$R_{k}$ - characteristic value of the ultimate resistance of the subsoil $[\mathrm{kN}]$,

$\Gamma_{R}$ - partial factor for checking the ultimate resistance of the subsoil, $\Gamma_{R}=1.4$,

$A^{\prime}=B^{\prime} \cdot L^{\prime}-$ effective area of the foundation $\left[\mathrm{m}^{2}\right]$,

$B^{\prime}=B-2 e_{B}, L^{\prime}=L-2 e_{L}-$ effective width and length of the foundation [m],

$B, L$ - width and length of the foundation base $[\mathrm{m}]$,

$D_{\min }-$ depth of foundation [m],

g' - characteristic unit weight of soil below the foundation level $\left[\mathrm{kN} \cdot \mathrm{m}^{-3}\right]$, $q^{\prime}$ - characteristic stress value of overburden at the foundation level [kPa], $c^{\prime}{ }_{k}, f^{\prime}{ }_{k}$ - characteristic value of cohesion and the angle of internal friction of the soil directly below the foundation level [kPa],

$c_{u, k}$ - undrained shear strength, $\mathrm{kPa}$, $N_{C}, N_{q}, N_{\mathrm{g}}$ - bearing capacity factors calculated basing on the characteristic value of the angle of internal friction $f^{\prime}{ }_{k}[-]$,

$s_{c}, s_{q}, s_{g}-$ coefficients of the shape of the foundation base [-],

$g-$ acceleration of gravity, $\left[\mathrm{m} \cdot \mathrm{s}^{-2}\right]$.

There were omitted in the calculations coefficients of inclination of the foundation base, as it was assumed that it is horizontal, and coefficients of inclination of the load resulting from the horizontal load, since the occurrence of this type of interaction was not expected. 


\section{TESTS RESULTS AND THEIR ANALYSIS}

\section{Physical properties}

A silt fraction dominated in the granulometric composition of the fly ash, and its content was on average $74 \%$, clay fraction $-22 \%$, and sand $-4 \%$. According to the geotechnical nomenclature [BS-EN-ISO-14688: 2006], the fly ash was classified as several-fractional clayey silt (Table 2). The density of solid particles was

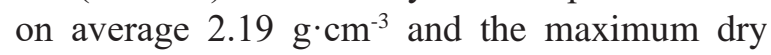
density of solid particles $-1.12 \mathrm{~g} \cdot \mathrm{cm}^{-3}$ at the optimum moisture content of $35 \%$.

Table 2. Basic geotechnical characteristics of fly ash

\begin{tabular}{|l|c|}
\hline \multicolumn{1}{|c|}{ Parameter } & Value \\
\hline Fraction content [\%]: & \\
- sand Sa $(0.063-2 \mathrm{~mm})$, & 4 \\
- silt Si $(0.002-0.063 \mathrm{~mm})$, & 74 \\
- clay Cl (<0.002 $\mathrm{mm})$. & 22 \\
\hline Soil name acc. to [PN-EN-ISO-14688-2:2006] & $\begin{array}{c}\mathrm{clSi} \\
\text { (clayey silt) }\end{array}$ \\
\hline Density of solid particles [g. $\left.\mathrm{cm}^{-3}\right]$ & 2.19 \\
\hline Optimum moisture content [\%] & 35.0 \\
\hline Maximum dry density of solid particles $\left[\mathrm{g} \cdot \mathrm{cm}^{-3}\right]$ & 1.12 \\
\hline
\end{tabular}

\section{Undrained shear resistance}

The highest values of the shear strength, from 88 to $422 \mathrm{kPa}$, were obtained using the pocket penetrometer for the range of moisture content from 29 to $40 \%$. High values, from 38 to 298 $\mathrm{kPa}$, were also obtained using the cone penetrometer, and the lowest, from 33 to $45 \mathrm{kPa}$, using the shear vane tester (Figure 5) for the same range of moisture content. Whereas the values obtained from the laboratory vane apparatus, from 40 to $229 \mathrm{kPa}$, were similar to those from the cone penetrometer tests.

When analyzing the effect of moisture content, it was found that the highest values of the undrained shear strength were obtained at the moisture content by $5 \%$ less than the optimum one, and the lowest values at the highest moisture content, that is by $5 \%$ bigger than the optimum one. The reduction in shear strength with increasing moisture content from 29 to $40 \%$, at the compaction index $\mathrm{I}_{\mathrm{S}}=0.90$, ranged from 7 $\mathrm{kPa}$ while using the shear vane tester, to $266 \mathrm{kPa}$ while using the pocket penetrometer. In the case of the laboratory vane apparatus and the cone penetrometer, the reduction in shear strength was respectively by 82 and $155 \mathrm{kPa}$. Similarly, at the degree of compaction $\mathrm{I}_{\mathrm{S}}=1.00$ decrease in the shear strength ranged from 11 to $329 \mathrm{kPa}$, respectively, using shear vane tester and the pocket penetrometer. For the other two apparatuses, there was also a large decrease in the shear strength, and equalled $111 \mathrm{kPa}$ for the laboratory vane apparatus and $232 \mathrm{kPa}$ for the cone penetrometer. As can be seen from the above analysis, the scope of the shear strength at the given compaction between the assumed moisture contents depended on the used apparatus. The biggest differences occurred for the pocket penetrometer, which can be explained by plastifying the ash together with the increase in moisture content and decrease in resistance when pressing the penetrometer. Whereas the lowest differences were stated for the shear vane tester, which can be explained by the nearto-surface reach of its vane influence.
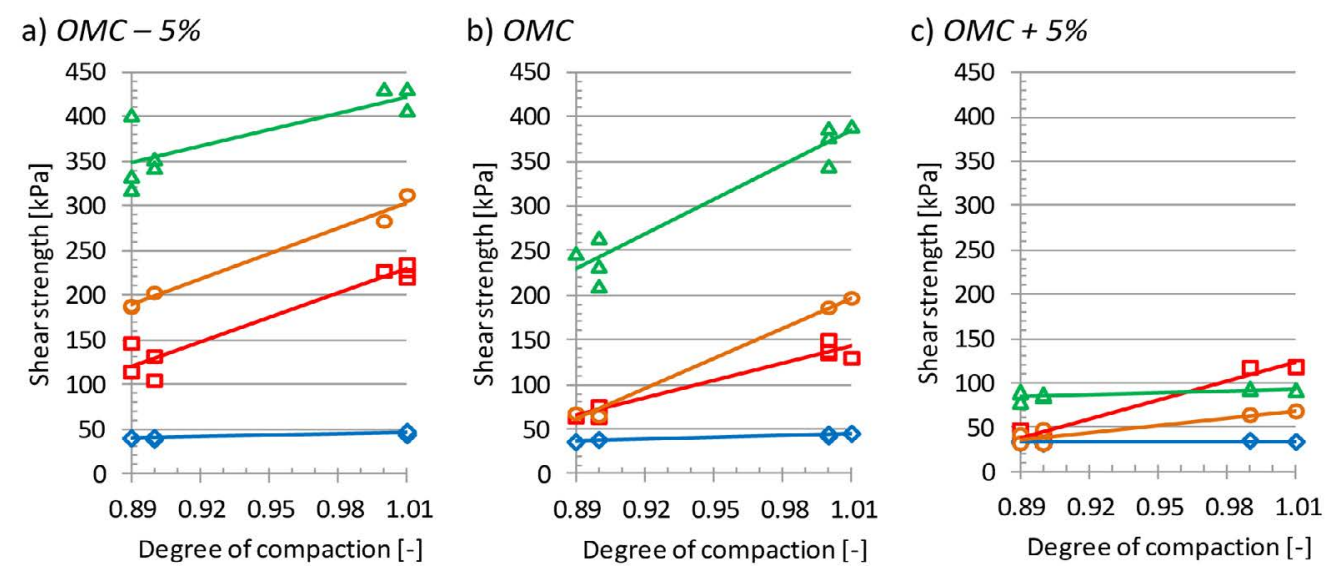

$$
\begin{aligned}
& -\square \text { - Laboratory vane apparatus }-0-\text { Cone penetrometer } \\
& -\triangle \text { Pocket penetrometer } \quad \sim \text { Shear vane tester }
\end{aligned}
$$

Figure 5. Shear strength versus compaction at various moisture content of the fly ash (OMC - optimum moisture content) 
a) at the degree of compaction $I_{S}=0.90$

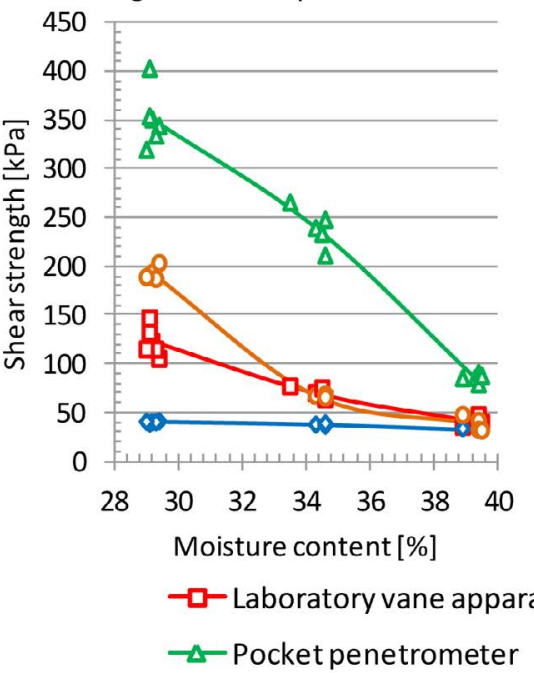

b) at the degree of compaction $I_{S}=1.00$

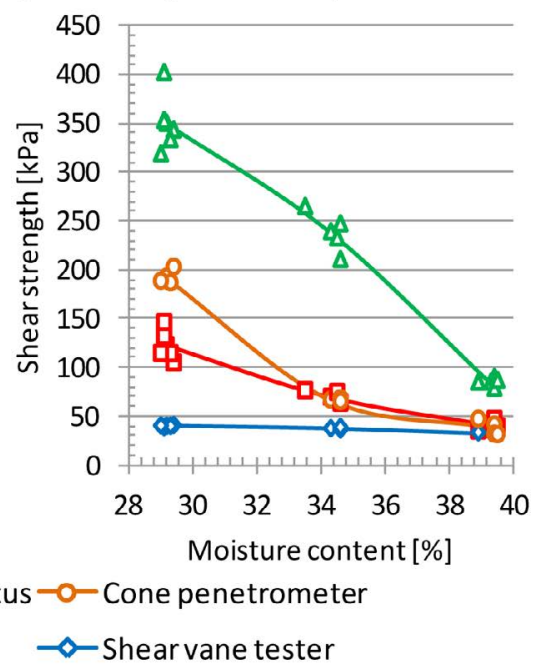

Figure 6. Shear strength versus moisture content at various compaction of the fly ash

The increase in the density from $\mathrm{I}_{\mathrm{S}}=0.90$ to 1.00 resulted in the increase in the undrained shear strength (Figure 6). The biggest increases from 1.6 to 2.9 -fold and from 1.9 to 2.4 -fold were observed using respectively the cone penetrometer and the vane apparatus. When using the shear vane tester and the pocket penetrometer, the increase in shear strength along with the increase in compaction was also achieved. However, it was small in comparison with the other apparatuses and ranged from 1.1 to 1.2 -fold.

The obtained results showed that the laboratory vane apparatus and the cone and pocket penetrometers were considerably susceptible to changes of moisture content and compaction while assessing the undrained shear strength. In contrast, the values of the shear strength obtained using the shear vane tester were characterized by small changes along with increasing the moisture content and compaction, which can cause problems in the interpretation of the tests results. Therefore, the use of the laboratory vane apparatus and the cone penetrometer, due to the relatively large convergence of the obtained results seems to be purposeful to determine the strength characteristic of the fly ash. Whereas the test results obtained using the pocket penetrometer and the shear vane tester should be treated as indicative, and their use in engineering practice in the design calculations is inadvisable. It should be noted, however, that the tests, which are considered as complementary, as is the case with the pocket penetrometer and the shear vane tester can be useful while docu- menting the subsoil and can provide an assessment of, for example, the consistency of cohesive soils [Majer and Pietrzykowski 2013].

\section{Angle of internal friction and cohesion}

The analysis of the obtained results of the angle of internal friction and cohesion of the fly ash showed large values of the latter at the insignificant impact of the compaction. Together with the increase in the density from IS $=0.90$ to 1.00 , the increase in the angle of internal friction was slightly more than $2^{\circ}(8 \%$ relatively) and in the case of consistency at the moisture content close to the optimum one - close to $2 \mathrm{kPa}(6 \%$ relatively) (Figure 7). A similar relationship was observed for other fuel ashes and reported in the works of other authors [Gruchot 2009, Zydroń and Zawisza 2004].

\section{CALCULATIONS OF THE ULTIMATE RESISTANCE OF THE SUBSOIL}

The calculations of the ultimate resistance of the subsoil were carried out for the pad foundation of the width and length $B=L=1.0 \mathrm{~m}$, founded at the depth of $D=1.0 . \mathrm{m}$. It was assumed that the subsoil is fly ash, which was characterized by the compaction corresponding to the degree of compaction $\mathrm{I}_{\mathrm{S}}=0.90$ and 1.00 . The unit weight of the ash at $\mathrm{I}_{\mathrm{S}}=0.90$ was $13.34 \mathrm{kN} \cdot \mathrm{m}^{-3}$, and at $\mathrm{I}_{\mathrm{S}}=$ $1.00-14.81 \mathrm{kN} \cdot \mathrm{m}^{-3}$, which corresponded to the pressure at the depth of the foundation, 13.34 and $14.81 \mathrm{kPa}$ respectively (Table 3 ). 
a)

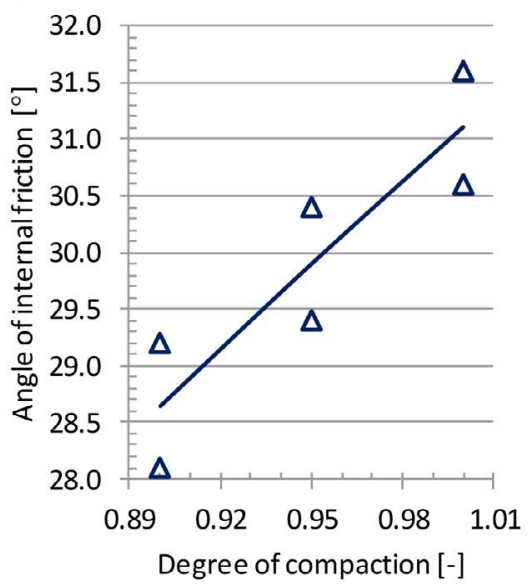

b)

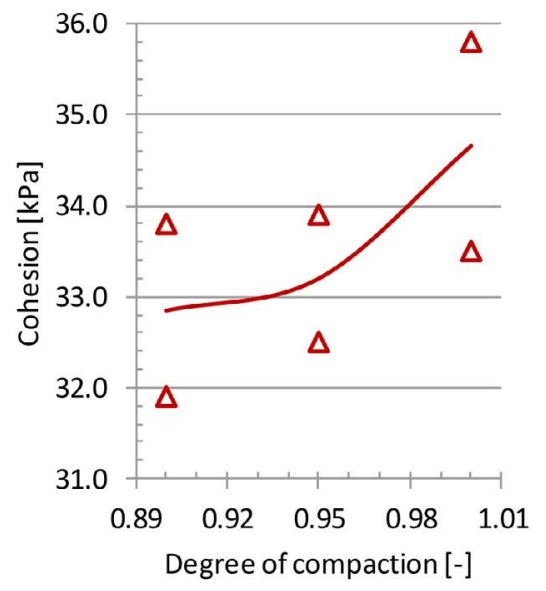

Figure 7. Angle of internal friction (a) and cohesion (b) versus compaction of the fly ash

Table 3. The results of calculations of the ultimate resistance of the subsoil according to [PN-EN 1997-1:2008]

\begin{tabular}{|c|c|c|c|c|c|c|c|}
\hline Parameter & Symbol & \multicolumn{6}{|c|}{ Value } \\
\hline Subsoil conditions & - & \multirow{2}{*}{\multicolumn{2}{|c|}{$\begin{array}{c}\text { drained } \\
\text { direct shear } \\
\text { apparatus }\end{array}$}} & \multicolumn{4}{|c|}{ undrained } \\
\hline The equipment used & - & & & \multicolumn{2}{|c|}{$\begin{array}{l}\text { laboratory vane } \\
\text { apparatus }\end{array}$} & \multicolumn{2}{|c|}{ cone penetrometer } \\
\hline Degree of compaction & $I_{s}$ & 0.90 & 1.00 & 0.90 & 1.00 & 0.90 & 1.00 \\
\hline Angle of internal friction $\left[^{\circ}\right]$ & $f_{k}$ & 28.7 & 31.1 & - & - & - & - \\
\hline Cohesion $[\mathrm{kPa}]$ & $c_{k}$ & 32.9 & 34.7 & - & - & - & - \\
\hline Undrained shear strength $[\mathrm{kPa}]$ & $c_{u, k}$ & - & - & 69.3 & 137.9 & 66.4 & 197.7 \\
\hline Bearing capacity coefficient [-] & $\begin{array}{l}N_{c} \\
N_{q} \\
N_{g}\end{array}$ & $\begin{array}{l}15.90 \\
27.22 \\
16.32 \\
\end{array}$ & $\begin{array}{l}20.87 \\
32.94 \\
23.97 \\
\end{array}$ & & & & \\
\hline Shape coefficient [-] & $\begin{array}{l}S_{c} \\
S_{q} \\
S_{g}\end{array}$ & $\begin{array}{l}1.48 \\
1.51 \\
0.70 \\
\end{array}$ & $\begin{array}{l}1.52 \\
1.54 \\
0.70 \\
\end{array}$ & & & & \\
\hline Ultimate resistance - characteristic value $[\mathrm{kN}]$ & $R_{k}$ & 1744.7 & 2356.1 & 440.9 & 864.2 & 423.0 & 1196.1 \\
\hline Ultimate resistance - design value $[\mathrm{kN}]$ & $R_{d}$ & 1246.2 & 1668.9 & 314.9 & 617.3 & 302.2 & 854.4 \\
\hline
\end{tabular}

The carried out calculations showed that the values of the ultimate resistance of the drained and undrained subsoil significantly varied depending on the method of determination of the undrained shear strength and compaction. The ultimate resistance of the drained subsoil made of the fly ash at the degree of compaction $\mathrm{I}_{\mathrm{S}}=0.90$ was on average 4 times bigger than the ultimate resistance of the undrained subsoil obtained from the calculations of the undrained shear strength using the laboratory vane apparatus and the cone penetrometer (Table 3). Whereas at the degree of compaction $\mathrm{I}_{\mathrm{s}}=1.00$, the ultimate resistance of the drained subsoil was bigger than the ultimate resistance of the undrained subsoil: 2.7 times in the case of the undrained shear strength obtained using the laboratory vane apparatus and 2 times in the case of the undrained shear strength obtained using the cone penetrometer.

When carrying out the calculations of the ultimate resistance of the drained subsoil, it is recommended using the effective shear strength parameters of the subsoil under the foundation, and thus taking into account the pore water pressure. The conducted tests of the angle of internal friction and cohesion of the fly ash in the direct shear apparatus, despite applying the small shearing velocity, do not allow defining these parameters as effective. Therefore, in the following part of the calculations, the obtained shear strength parameters were reduced to values at which the ultimate resistance of the drained subsoil was equal to the resistance of the undrained subsoil. These calculations were carried out in 
two variants. The first assumed that the angle of internal friction was determined correctly, and the cohesion was reduced. It was assumed that its high values resulted from blocking rough fly ash particles and the high content of the sand fraction. In the second variant of the calculations, both shear strength parameters - the angle of internal friction and cohesion - were reduced, assuming the reduction factor from 1.0 to 1.7.

The first variant of the carried out calculations revealed that the cohesion of the fly ash should be reduced to the value slightly above $1 \mathrm{kPa}$ at $\mathrm{I}_{\mathrm{S}}=$ 0.90 and above $5 \mathrm{kPa}$ at $\mathrm{I}_{\mathrm{S}}=1.00$, so that the values of the ultimate resistance of the undrained and

a) laboratory vane apparatus

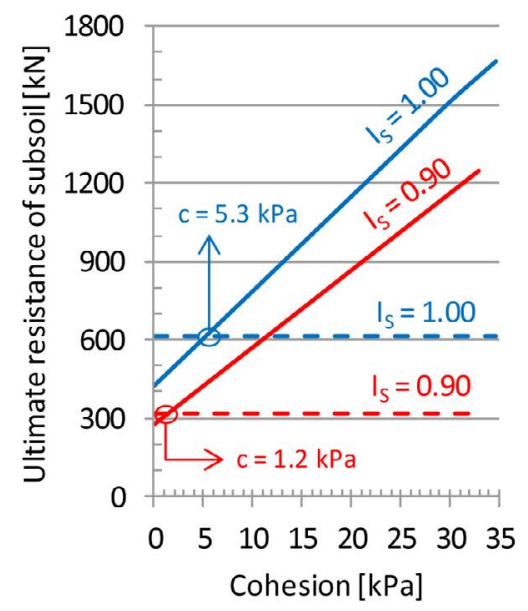

drained subsoil were equal taking the undrained shear strength from the laboratory vane apparatus (Figure 8). In the case of the tests using the cone penetrometer, the ultimate resistances at the undrained and drained conditions were equal at the cohesion close to $1 \mathrm{kPa}$ at $\mathrm{I}_{\mathrm{S}}=0.90$ and $12 \mathrm{kPa}$ at $\mathrm{I}_{\mathrm{S}}=1.00$. The calculations performed show the significant impact of the cohesion on the values of the ultimate resistance of the subsoil. Therefore, in the case of fine-grained wastes or where the cohesion results from the mutual blocking of grains, it is suggested to carry out the tests of the angle of internal friction and cohesion in conditions of hydration of the shearing zone, or to reduce the b) cone penetrometer

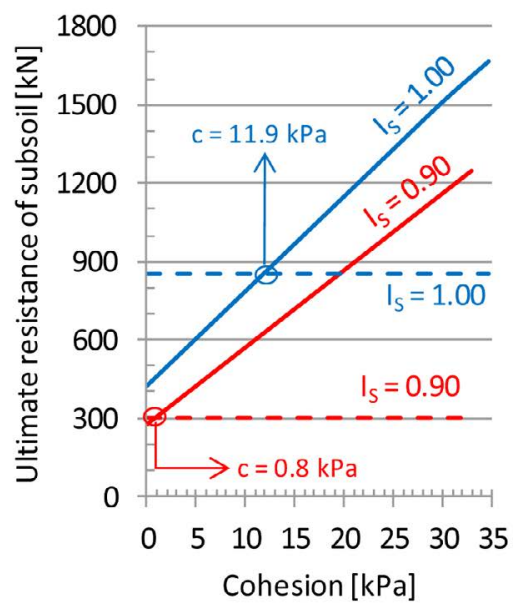

-1 design value of drained ultimate resistance design value of undrained ultimate resistance

Figure 8. The dependence of the ultimate resistance of the drained subsoil on the cohesion at the constant value of the angle of internal friction from the direct shear apparatus tests

a) laboratory vane apparatus

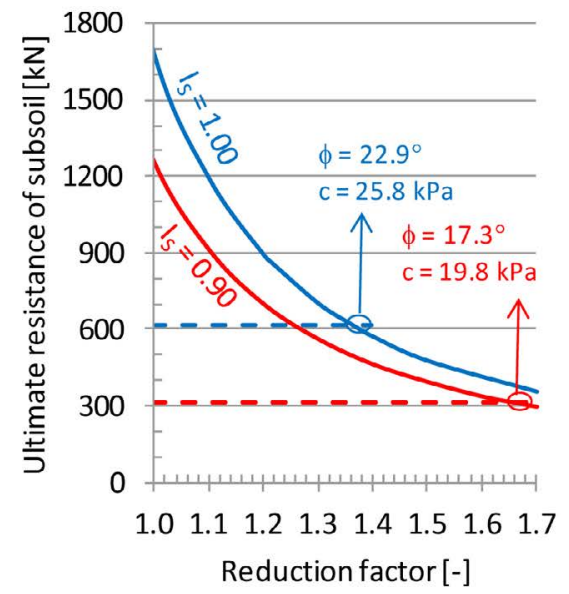

b) cone penetrometer

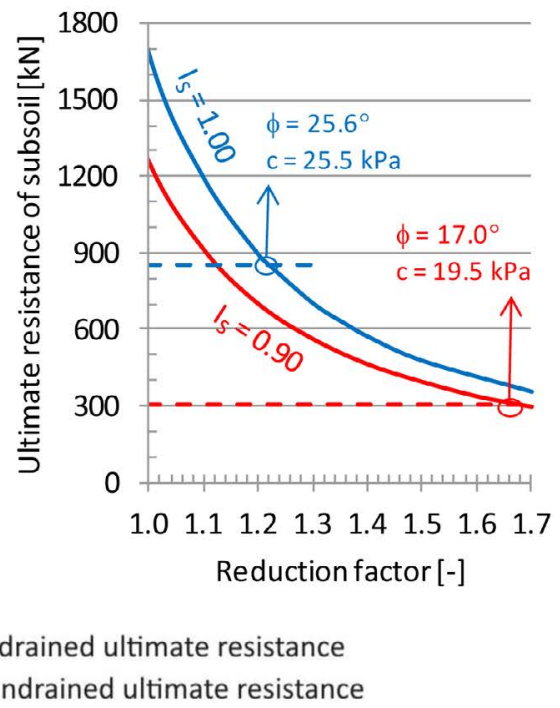

Figure 9. Decrease in the ultimate resistance of the drained subsoil at the reduction in the angle of internal friction and cohesion 
cohesion in the case of calculations of the ultimate resistance of the subsoil.

The analysis of the ultimate resistance of the subsoil in the second variant of the calculations, with reduction in both shear strength parameters revealed the necessity of their significant reduction to obtain convergence of the values of the ultimate resistance in the drained and undrained conditions. Getting the same values of the ultimate shear resistance of the subsoil required the reduction in the angle of internal friction and cohesion 1.7-fold at $\mathrm{I}_{\mathrm{S}}-0.90$ and 1.4-fold at $\mathrm{I}_{\mathrm{S}}=$ 1.00 in the laboratory vane apparatus tests of the undrained shear resistance (Figure 9). Whereas in the case of the cone penetrometer, reduction in the shear strength parameters was 1.7 -fold at $\mathrm{I}_{\mathrm{S}}-$ 0.90 and 1.2 -fold at $\mathrm{I}_{\mathrm{S}}=1.00$.

\section{CONCLUSIONS}

The conducted study revealed that the fly ash from the Power Plant "Skawina" was characterized by high values of the undrained shear strength and the angle of internal friction and cohesion. The obtained results of these parameters made it possible to obtain high values of the ultimate resistance of the subsoil.

The biggest values of the shear strength were obtained from the tests with the piston penetrometer, and the lowest for the handheld shear vane tester. This confirms that the use of these apparatuses as indicators in assessing the shear strength of soil is right. And the results of the cone penetrometer and laboratory vane apparatus were close and it is suggested to use them in calculations of the ultimate resistance of the undrained subsoil. The analysis of the impact of compaction and moisture content revealed that those parameters significantly affected the values of the shear strength.

The ultimate resistance of the drained subsoil made of the fly ash was several times bigger than the value for the undrained subsoil. That is why research aiming at the determination of the strength properties of fly ashes should be carried out with great care and with the possibility of verifying the obtained results in situ.

\section{REFERENCES}

1. Baran P., Cholewa M., Zawisza E., Kulasik K. 2013. Problem jednoznacznego ustalenia parametrów wytrzymałości na ścinanie odpadów po- węglowych i poenergetycznych Annual Set The Environment Protection - Rocznik Ochrona Środowiska, 15, 2071-2089.

2. Glinicki S.P. 1995. Geotechnika budowlana. Część 1, Wydawnictwo Politechniki Białostockiej, Białystok.

3. Gruchot A. 2009. Charakterystyka geotechniczna wybranych odpadów poenergetycznych w aspekcie wykorzystania ich do budownictwa drogowego, Wydawnictwo Uczelniane UTP, Bydgoszcz, 253-258.

4. Gruchot A., Zydroń R., Gałowicz E. 2015. Parametry wytrzymałościowe fluidalnego popiołu lotnego z Elektrowni „Połaniec”. Annual Set The Environment Protection - Rocznik Ochrona Środowiska, $17,498-518$.

5. Majer E., Pietrzykowski P. 2013. Propozycja obiektywizacji makroskopowej oceny konsystencji penetrometrem tłoczkowym. Acta Scientiarum Polonorum, Seria Architectura, 12 (3), 175-181.

6. Myślińska E. 2006. Laboratoryjne badania gruntów, Wydawnictwo Uniwersytetu Warszawskiego, Warszawa.

7. Pisarczyk S. 2009. Grunty nasypowe, Oficyna Wydawnicza Politechniki Warszawskiej, Warszawa.

8. Zabielska-Adamska K. 2006. Popiół lotny jako materiał do budowy warstw uszczelniających, Wydawnictwo Politechniki Białostockiej, Białystok.

9. Zawisza E., Zydroń T. 2004. Badania wpływu zagęszczenia i wilgotności na wytrzymałość na ścinanie popiołów lotnych, XI Międzynarodowa Konferencja „Popioły z energetyki”, Wydawnictwo Ekotech Sp. z o.o., 255-266.

10. PKN-CEN ISO/TS 17892-3:2009. Badania geotechniczne. Badania laboratoryjne gruntów. Część 3. Oznaczenie gęstości właściwej. Metoda piknometru. Polski Komitet Normalizacyjny, Warszawa.

11. PKN-CEN ISO/TS 17892-6:2009. Badania geotechniczne. Badania laboratoryjne gruntów. Część 6: Badanie penetrometrem stożkowym. Polski Komitet Normalizacyjny, Warszawa.

12. PKN-CEN ISO/TS 17892-10:2009. Badania geotechniczne. Badania laboratoryjne gruntów. Część 10: Badanie w aparacie bezpośredniego ścinania. Polski Komitet Normalizacyjny Warszawa.

13. PN-B-04481:1988. Grunty budowlane. Badania próbek gruntu. Polski Komitet Normalizacyjny, Warszawa.

14. PN-EN 1997-1:2008. Eurokod 7. Projektowanie geotechniczne. Cz. 1: Zasady ogólne. Polski Komitet Normalizacyjny Warszawa.

15. PN-EN ISO 14688-2:2006. Badania geotechniczne. Oznaczanie i klasyfikowanie gruntów. Część 2: Zasady klasyfikowania. Polski Komitet Normalizacyjny Warszawa. 